\title{
Bacterial biofilms as a trophic resource for certain benthic foraminifera
}

\author{
Joan M. Bernhard ${ }^{1}$, Samuel S. Bowser ${ }^{1,2, *}$ \\ 'Wadsworth Center for Laboratories and Research, PO Box 509, Albany, New York 12201-0509, USA \\ ${ }^{2}$ Department of Biomedical Sciences, State University of New York, 1400 Washington Avenue, Albany, New York 12222, USA
}

\begin{abstract}
Benthic foraminifera from temperate tidal flats and shallow Antarctic waters were challenged with bacterial biofilms to assess possible foraminiferal impact on attached bacterial populations. Two tectinous species (Allogromia sp. and A. laticollaris) used pseudopodial networks to rend and ingest biofilm parcels, an activity we term harvesting. The numerical density of bacteria in harvested biofilm areas was maximally depleted by ca $80 \%$ for Allogromia sp. and $50 \%$ for $A$. laticollaris. In contrast, the calcareous (Cyclogyra antarctica, Elphidium incertum, Glandulina antarctica, Pyrgo williamsoni) and agglutinated (Astrammina rara, Astrorhiza sp., Crithionina-like mudball) foraminifera studied did not exhibit harvesting behavior. Time-lapse microscopy revealed that biofilm parcels were transported extracellularly toward the cell body by pseudopodia, an observation which further defines pseudopodial function in foraminiferal trophic mechanisms. Our observations indicate that allogromiid foraminifera may play a previously unrecognized role in bacterial population dynamics and nutrient cycling, particularly in intertidal environments and certain deep-sea habitats where they may constitute a major meiofaunal component.
\end{abstract}

\section{INTRODUCTION}

In aquatic environments, solid surfaces provide a nutrient-rich microenvironment relative to the water column, and therefore support the enhanced growth of attached microorganisms (Zobell 1943). This association of microorganisms and their extracellular products (i.e. organic polymer matrix) with a solid surface is termed a biofilm (for reviews, see McFeters et al. 1984, Costerton et al. 1987, Characklis \& Marshall 1990). Bacterial biofilms are widespread in the marine realm (reviewed in Blenkinsopp \& Costerton 1991), occurring, for example, on macrophytes and sand grains (Jones 1982, DeFlaun \& Mayer 1983). The organisms that consume bacterial biofilms are thought to function as important intermediates in benthic nutrient cycling (Gerlach 1978, Paerl 1984).

Benthic foraminifera are a diverse and abundant group of rhizopod protists that consume bacteria

\footnotetext{
- Addressee for correspondence; address: Wadsworth Center for Laboratories and Research. PO Box 509. Albany, New York 12201-0509, USA
}

(Bradshaw 1961, Muller \& Lee 1969, Lipps \& Valentine 1970, Frankel 1975, Lee 1979, Lipps 1983) and thus might significantly contribute to marine nutrient cycling. Most data in support of this understanding come from laboratory radiotracer studies in which foraminifera were shown to consume suspended or recently settled bacteria (Lee et al. 1966, Lee \& Muller 1973, Alexander \& DeLaca 1987). However, little or no information is available regarding the impact of foraminifera on attached bacteria, particularly bacterial biofilms, even though foraminifera and biofilms commonly occur in the same habitats.

To gain insight into the possible role of foraminifera in biofilm turnover, we challenged various foraminifera from temperate salt marshes and shallow Antarctic waters with bacterial biofilms grown in the laboratory. Direct counting of fixed material and time-lapse videomicroscopy of living specimens were used to assess the impact of foraminifera on these surfaceattached bacteria over a time course of 12 to $48 \mathrm{~h}$. We found that 2 species of allogromiid foraminifera dramatically harvested biofilms, while the agglutinated and calcareous species examined showed no 
such activity. Because allogromiids comprise a large proportion of the benthic foraminiferal assemblage in certain marine habitats, including intertidal regions (Ellison 1984), deep-sea trenches (Jumars \& Hessler 1976), and deep-sea phytodetritus (Gooday 1988), our studies raise the possibility that benthic nutrient cycles may be notably influenced by these foraminifera in a previously unrecognized manner.

\section{MATERIALS AND METHODS}

Specimens. Allogromia sp. strain NF (Lee \& Pierce 1963) was cultured on agar plates ( $2 \% \mathrm{agar}_{\text {; }} \mathrm{wt} / \mathrm{vol}$. seawater) as described by Allen (1964). Allogromia laticollaris (Arnold) was cultured in $26 \%$ Føyn's Erdschreiber in seawater as described by Travis \& Allen (1981). Astrammina rara, Astrorhiza sp., Cyclogyra antarctica, Glancuiina antarctica, Pyrgo williamsoni and a Crithionina-like mudball were collected from 26 to $28 \mathrm{~m}$ depth at Explorers Cove, New Harbor (western McMurdo Sound, Antarctica). An air-lift dredge system operated by SCUBA divers delivered sediment to the surface, where it was passed through serial $5 \mathrm{~mm}$ and $1 \mathrm{~mm}$ sieves. Specimens were recovered from the $1 \mathrm{~mm}$ fraction using live insect collecting forceps (Fine Science Tools, Inc., Foster City, CA, USA). These specimens were kept on ice during transport to the United States, whereafter they were maintained at 0 to $2^{\circ} \mathrm{C}$ in marine aquaria. Elphidium incertum, a calcareous foraminifer which husbands diatom chloroplasts, was collected from the Great Sippewissett Salt Marsh (Falmouth, Massachusetts, USA) using methods outlined in Arnold (1974). Clean glass microscope slides were placed in Elphidiumenriched sediments, and specimens that migrated up the slides were removed using a fine pipet.

Experimental procedures. Unless otherwise stated, artificial seawater (Marin Tropic, Dr Biener Aquarientechnik, Germany) was used throughout this study. Biofilms were prepared by placing acid-washed and flamed $22 \mathrm{~mm}$ square coverslips into Petri dishes containing an enriched seawater medium $(5 \%$ Bacto peptone and $1 \%$ Bacto yeast extract (DIFCO Laboratories, Detroit, MI, USA] in artificial seawater). Seawater from the Great Sippewisset Salt Marsh, McMurdo Sound, or Allogromia sp. cultures was passed through $1.5 \mu \mathrm{m}$ Millipore filters and used as inocula. In preliminary studies we found that each of these 3 inocula yielded morphologically distinct bacterial populations which were optimal for use within $10 \mathrm{~d}$ of incubation at room temperature or $3 \mathrm{~d}$ at $30^{\circ} \mathrm{C}$. Prior to use, the biofilmcoated coverslips were dipped extensively in $0.2 \mu \mathrm{m}$ filtered seawater to remove unattached bacteria and then placed in Petri dishes containing $0.2 \mu \mathrm{m}$ filtered seawater.
Individual foraminifera were cleaned of adherent debris, if necessary, by gently rolling them on clean agar plates using a fine hair brush or glass microneedle. The agglutinated test of Astrammina rara was removed to enhance pseudopodial deployment and cell migration (Bowser \& DeLaca 1985a). Individual foraminifera were then plated onto the biofilm-laden coverslips and incubated for 12 to $48 \mathrm{~h}$ after pseudopodial extension (which, for Antarctic specimens, often required several days). For the allogromiids, 1 to 3 specimens were widely spaced on each coverslip to ensure that interactions between individuals were minimized. After incubation, the coverslips were immersed in fixative (3\% glutaraldehyde in $0.1 \mathrm{M}$ cacodylate buffer containing $1.5 \mathrm{mg} \mathrm{ml}^{-1}$ ruthenium red) for $2 \mathrm{~min}$. Samples were then rinsed in distilled water, air-dried, and mounted in water. Specimens were examined and photographed using a Nikon Optiphot light microscope equipped with survey dark field and high-resolution phase-contrast optics, and a UFX photomicrographic system. All magnifications were calibrated using the $10 \mu \mathrm{m}$ ruled spacings of a stage micrometer.

Estimates of bacterial numbers were made by photographing $57 \mu \mathrm{m}$ by $38 \mu \mathrm{m}$ fields from areas of obvious foraminiferal involvement, as well as unimpacted regions away from the foraminifera. For each specimen, 5 fields were photographed within impacted areas, 5 in undisturbed areas adjacent to the specimen, and if applicable, 5 fields in transition areas. The number of bacteria in these regions was directly counted by standard practices in each of eight $0.5 \times 0.5 \mathrm{~cm}$ squares (representing $\sim 500 \mu^{2}$ \} from each negative. Where practical, low-magnification $(10 \times)$ photographs were digitized and the area impacted by the foraminifera was determined using custom image analysis software (see Marko et al. 1988).

To assess bacterial ingestion by allogromiids, biofilm-laden coverslips, derived from the Allogromia sp. culture inoculum, were incubated for $30 \mathrm{~min}$ in seawater containing $10 \mu \mathrm{g} \mathrm{ml}^{-1}$ Hoechst 33342 (a DNAspecific fluorochrome) and then rinsed with filtered seawater. Specimens of Allogromia sp. or A. laticollaris were incubated on these fluorescently-labeled biofilms for $6 \mathrm{~h}$. As controls, replicate preparations were continuously treated with $1 \mathrm{mM}$ colchicine to inhibit the extension of pseudopodia (see Travis \& Bowser 1991), and thus prevent biofilm harvesting. Specimens were removed from the biofilms, cleaned of adherent material, and then fixed in $6 \%$ glutaraldehyde $/ 0.1 \mathrm{M}$ cacodylate buffer Mounted specimens were examined through-focus using a Nikon Optiphot epifluorescence microscope equipped with a $60 \times$ PlanApo objective (NA 1.4) and UV-1A filter pack.

For direct videomicroscopic observation of biofilm harvesting by allogromiids, a $16 \mathrm{~mm}$ hole was fash- 
ioned in the bottom of a $35 \mathrm{~mm}$ plastic Petri dish, over which an $18 \mathrm{~mm}$ coverslip was sealed using VALAP (a mixture of equal parts Vaseline, lanolin, and paraffin). After bacterial inoculation, the dishes were incubated for 3 to $10 \mathrm{~d}$, and then the coverslip 'window' was extensively rinsed with a stream of sterile seawater before plating with allogromiids. Time-lapse recordings of live specimens impacting biofilms were made using a Nikon Diaphot phase-contrast microscope equipped with a Dage-MTI model 65 video camera, which fed images to a Panasonic model 2028F optical memory disc recorder (OMDR). Incident illumination was passed through serial UV-cut and heat filters and pulsed using a Uniblitz shutter to minimize specimen irradiation. The OMDR and shutter were under the control of a PC-class microcomputer using custom software. OMDR time-lapse recordings were analyzed frame-by-frame to determine the dimensions of harvested biofilm parcels and their transport rates along pseudopodial networks.

To compare the movement rates of Allogromia sp. and A. laticollaris on biofilms and bare surfaces, specimens were photographed hourly using a Nikon stereomicroscope, and the distances traversed were measured directly from the negatives. Four specimens of each species were placed on a given biofilm to provide direct comparison. In some instances, time-lapse video records supplemented these data.

\section{RESULTS}

Examination of fixed specimens revealed that, within 12 h, Allogromia sp. impacted biofilms derived from all 3 inocula by leaving highly denuded regions (Fig. 1). The area of these harvested regions varied between 0.3 and $8.6 \mathrm{~mm}^{2}$ (Table 1). Closer examination revealed that most ( 6 of 7 ) specimens moved during the course of incubation, leaving both intensely harvested regions and moderately impacted (transitional) areas on the biofilm (Fig. 2). Approximately $80 \%$ of the bacteria contained in unaffected areas were removed by the foraminifera, whereas about $33 \%$ were removed in transitional regions (Table 2; Fig. 3a, b, c).

Allogromia laticollaris similarly impacted the biofilms, although this species did not harvest bacteria as effectively as Allogromia sp. (Table 2). In general, the areas impacted by $A$. laticollaris were smaller and widely dispersed, and the maximal proportion of bacteria removed in harvested regions was $50 \%$ of those seen in unaffected areas.

Correlative phase-contrast and epifluorescence microscopy revealed that $89 \%$ of the bacteria within biofilms pretreated with Hoechst 33342 were labelled with this DNA-binding fluorochrome. When Allogro-
Table 1. Allogromia sp. Area harvested $\left(\mathrm{mm}^{2}\right)$

\begin{tabular}{|ccc|}
\hline Specimen & Harvested area & Area harvested $\mathrm{h}^{-1}$ \\
\hline 1 & 1.20 & 0.09 \\
2 & 0.28 & 0.02 \\
3 & 2.04 & 0.16 \\
4 & 0.54 & 0.04 \\
5 & 4.04 & 0.25 \\
6 & 8.56 & 0.54 \\
7 & 4.34 & 0.27 \\
\hline
\end{tabular}

mia sp. harvested these labelled biofilms, numerous fluorescent bacteria were seen throughout the animal's cytoplasm, indicating that biofilm parcels were internalized (Fig. 4a, b). Also seen were bacteria attached to the external surface of the allogromiid's test and up to 40 nuclei randomly distributed in its cytoplasm. (This nuclear staining was attributed to stain carryover during incubation and fixation.) Control specimens continuously treated with the microtubule poison colchicine, which inhibited biofilm harvesting by preventing pseudopodial deployment, also showed fluorescent test-associated bacteria and numerous nuclei, but no fluorescent objects resembling bacteria within the cytoplasm (Fig. 5c,d). This latter finding ruled out the possibility that the internal bacteria seen in activelyharvesting specimens represented endosymbionts rather than phagocytosed biofilm parcels. Similar results were obtained in parallel experiments using $A$. laticollaris, although the large number of pigmented lipid droplets characteristic of this species hampered photomicroscopy (data not shown). Together, these findings indicate that Allogromia internalizes a portion of the bacteria harvested from biofilms, and therefore most likely uses them as a food source.

In contrast to the results obtained with allogromiids, none of the agglutinated (Astrammina rara, Astrorhiza sp., Crithionina-like mudball) or calcareous (Elphidium incertum, Cyclogyra antarctica, Glandulina antarctica, Pyrgo williamsoni) foraminifera examined harvested biofilms derived from any of the inocula (e.g. Fig. 6a). A few larger, motile specimens of E. incertum, C. antarctica and Crithionina-like mudball formed a visible furrow in the biofilm as they dragged their bulky tests across the coverslips. Although we were unable to determine whether these specimens collected the dislodged bacteria, the area affected by such activity appeared negligible. Indeed, only one $E$. incertum impacted the biofilm sufficiently to warrant detailed examination; bacteria were depleted by ca $25 \%$ in the furrow left by this specimen (Table 2).

It was evident, however, that bacterial numbers were higher in areas immediately adjacent to extracellular components secreted by 3 of the agglutinated 

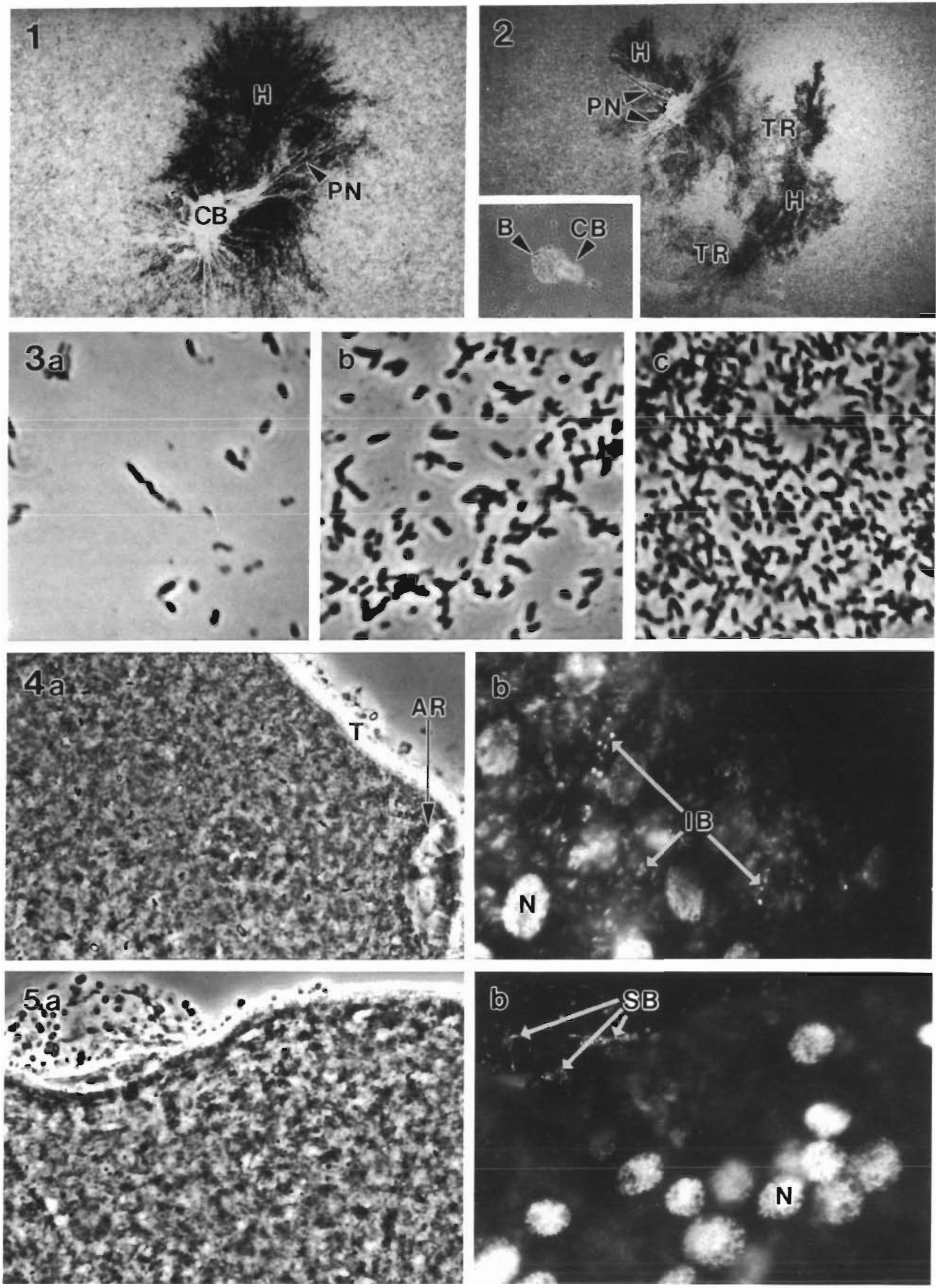
Table 2. Average number of bacteria present in $10 \mu \mathrm{m}^{2}$ areas either impacted (harvested or transitional areas) or ungrazed by specimens. Numbers in parentheses are standard deviations. NA = not applicable

\begin{tabular}{lccc|}
\hline Species & Harvested area & Transitional area & Ungrazed area \\
\hline Allogromia sp., $\mathrm{n}=7$ & $0.3(0.1)$ & $1.0(0.2 ; \mathrm{n}=3)$ & $1.6(0.6)$ \\
A. laticollaris, $\mathrm{n}=4$ & $1.3(0.7)$ & NA & $2.4(0.2)$ \\
Elphidium incertum, $\mathrm{n}=3$ & $1.7(\mathrm{n}=1)$ & NA & $2.2(0.1)$ \\
\hline
\end{tabular}

or calcareous foraminifera. Astrammina rara and Astrorhiza sp. secrete extracellular fibers in association with their pseudopodia; these fibers are thought to increase pseudopodial tensile strength to effect the capture of meiofaunal prey (Bowser et al. 1986, Bowser unpubl.). As seen in Fig. 6b, bacteria appear aggregated along these fibers. In Glandulina antarctica, bacteria were similarly concentrated on an unidentified filamentous substance, which appeared distinct from the extracellular fibers of Astrorhiza and Astrammina. In all of these instances it was unclear whether the bacteria were trapped by the foraminifer's fibers or whether the bacteria grew preferentially around them.

\section{Time-lapse observation of biofilm harvesting by allogromiids}

Time-lapse videomicroscopic recordings ${ }^{1}$ showed that Allogromia sp. typically extended pseudopodial networks 45 to $120 \mathrm{~min}$ after being plated on a biofilm. These networks were morphologically similar to those deployed on plain glass surfaces and consisted of numerous pseudopodial trunks, which distally branched and anastomosed to form a radially-dispersed array of finer reticulopodia. Concomitant with the extension of reticulopodia, specimens began harvesting the biofilm. Through-focus microscopy and close examination of time-lapse recordings showed that pseudopodial tips first penetrated the biofilm, which was subsequently deformed by tension developed within the pseudo- podial trunk. The granular appearance and flexible nature of thick biofilms permitted visualization of locally-applied pseudopodial tension (see also Travis et al. 1988). Trunk reticulopodia, either singly or in concert with several others, gradually exerted sufficient tension to remove a biofilm parcel from the substratum. Pseudopodial tension was typically exerted in only a small portion of the network, indicating local control of this process. It is noteworthy that reticulopodia were not observed to disladge individual bacteria, only biofilm parcels. Furthermore, harvesting activity appeared superimposed over other motile processes, such as the extension and bending of pseudopodia, bidirectional cytoplasmic transport, and cell locomotion.

A biofilm parcel was not phagocytosed at its site of formation within the pseudopodial network. Instead, parcels were transported along the extracellular surfaces of pseudopodial trunks (Fig. $7 \mathrm{a}, \mathrm{b}, \mathrm{c}$ ) to the apertural region, where they accumulated (inset, Fig. 2) and were eventually phagocytosed.

\section{Differential harvesting efficiency in allogromiids}

To gain insight into the observed differences in the efficiency of biofilm harvesting in the 2 allogromiid species, we examined several possible parameters,

\footnotetext{
${ }^{1}$ The observations reported in this section cannot be adequately reproduced as still figures. A videotape highlighting major features is available on loan from the authors
}

Figs. 1 to 5. Photomicrographs of Allogromia sp. on biofilms. Fig. 1. Dark-field micrograph of Allogromia sp. cell body (CB) and pseudopodial network (PN) fixed after $12.75 \mathrm{~h}$ incubation on biofilm. Dark area $(\mathrm{H})$ is harvested region. $\times 65$. Fig. 2. Dark-field micrograph of an Allogromia sp. which moved considerably during the $12.75 \mathrm{~h}$ incubation on biofilm. Note transitional harvested regions (TR). $\times 25$. Inset: Phase-contrast micrograph of live Allogromia sp. on biofilm. Original specimen underwent cytotomy; pictured is an offspring. Note large bolus of biofilm parcels (B) at apertural end of the cell body (CB). $\times 50$. Fig. 3 . Representative phase-contrast micrographs of (a) harvested, (b) transitional, and (c) unimpacted areas of a biofilm. $\times 1 \overline{953}$. Fig. 4. (a) Phasecontrast and (b) corresponding epifluorescence micrographs of Allogromia sp. after harvesting biofilm labelled with Hoechst 33342. In this optical section, note the apertural region (AR) and test (T). Nuclei (N) and numerous internalized bacteria (IB) are present in the cytoplasm. $\times 1100$. Fig. 5. (a) Phase-contrast and (b) corresponding epifluorescence micrographs of Allogromia sp. after incubation on Hoechst $3334 \overline{2}$-labelled biofilm in the presence of colchicine to prevent pseudopod deployment. Fluorescent nuclei (N) and surface-attached bacteria (SB) are seen, but fluorescently-labelled bacteria are absent from the foraminiferal cytoplasm. $\times 1100$ 

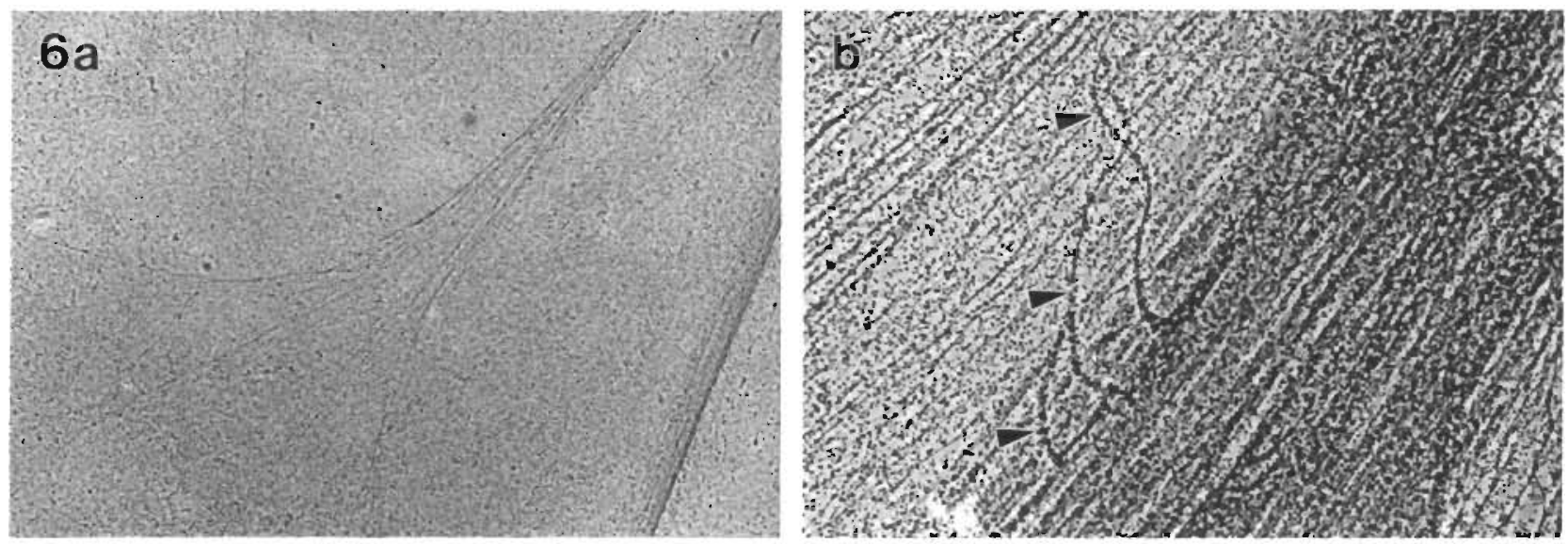

Fig. 6. Astrammina rara. Phase-contrast photomicrographs of a foraminifer fixed after $72 \mathrm{~h}$ incubation on biofilm. (a) Note absence of harvested regions. $\times 65$. (b) Higher magnification view of pseudopodial network showing bacteria associated with extracellular fibers (arrowheads). $\times 260$
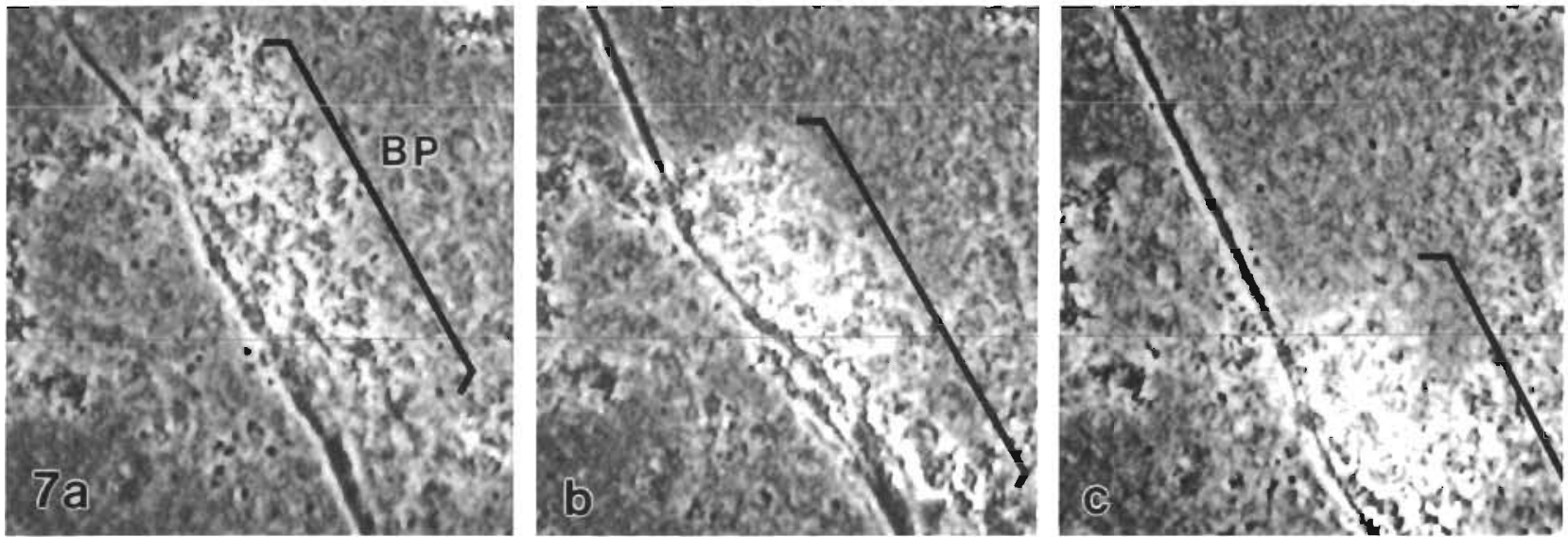

Fig. 7. Allogromia sp. Sequential phase-contrast videomicrographs illustrating transport of a biofilm parcel (BP) along the extracellular surface of a pseudopod. Time in seconds: (a) $0 ;$ (b) 44 ; (c) $76 . \times 693$

including the locomotory rate and residence time of individuals, as well as the size of biofilm parcels and their transport rates to the cell body. The range of movement exhibited by Allogromia laticollaris on biofilms was significantly greater $(\mathrm{p}=0.005)$ than that of Allogromia sp., as determined by a bootstrap analysis (see Efron \& Tibshirani 1991). The bootstrap samples were drawn with replacement from the combined data set, and range differences were calculated for 1000 bootstrap iterations. However, for each species, movement rates on biofilms were statistically similar to those on bare glass (Table 3; Mann-Whitney $U$-test; $\mathrm{p}>0.05$ ), indicating this is not a specific response to the food source. Although the congeners transported biofilm parcels toward the cell body at similar rates (Table 4 ; Mann-Whitney $U$-test; $p>0.05$ ), the average diameter of transported parcels in Allogromia sp. was significantly larger than that of $A$. laticollaris (Table 4; MannWhitney $U$-test, $\mathrm{p}<0.05)$. Thus, on the same biofilm, Allogromia sp. dislodged larger parcels as well as a wider range of parcel sizes than $A$. laticollaris, although the total fragment volume, and thus bacterial numbers, could not be determined.

Table 3. Allogromia sp., A. laticollaris. Comparison of allogromiid movement $\left(\mathrm{mm} \mathrm{h}^{-1}\right)$ on biofilms and bare surfaces

\begin{tabular}{|lccrcccc|}
\hline & \multicolumn{3}{c}{ Biofilm } & \multicolumn{3}{c|}{ Bare surface } \\
& $\bar{x}$ & SD & $\mathrm{n}$ & & $\bar{x}$ & SD & $n$ \\
\hline Allogromia sp. & 0.5 & 0.3 & 5 & 0.4 & 01 & 6 \\
A. laficollaris & 1.1 & 1.1 & 12 & 1.0 & 0.7 & 8 \\
\hline
\end{tabular}


Table 4. Allogramia sp., A. laticollaris. Comparison of parcel movement $\left(\mu \mathrm{m} \mathrm{s}^{-1}\right)$ and size (longest dimension) $(\mu \mathrm{m})$

\begin{tabular}{|lrrrrrrr|}
\hline & \multicolumn{3}{c}{ Parcel movement } & \multicolumn{3}{c|}{ Parcel length } \\
& $\bar{x}$ & SD & $\mathrm{n}$ & $\bar{x}$ & SD & $n$ \\
\hline Allogromiasp & 1.5 & 1.1 & 8 & 13.8 & 14.4 & 8 \\
A. laticollaris & 2.2 & 2.1 & 8 & 5.0 & 1.4 & 8 \\
\hline
\end{tabular}

\section{DISCUSSION}

Our laboratory observations show that certain foraminifera significantly impact bacterial biofilms, whereas other species show little or no impact. The 2 allogromiids studied were nonselective bacterial consumers, actively harvesting biofilms derived from 3 distinct inocula. Bacterial abundances in these harvested areas were depleted by up to $85 \%$. In contrast, the agglutinated and calcareous species examined crawled across these biofilm surfaces with no impact, except for a furrow produced by some motile specimens with particularly bulky tests, and increased numbers of bacteria associated with extracellular secretions of Astrammina rara, Astrorhiza sp., and Glandulina antarctica. Interestingly, electron microscopy shows that $A$. rara uses these extracellular secretions to tightly envelope meiofaunal prey such as cumaceans and amphipods (Bowser \& DeLaca 1985b); bacteria enclosed with the succumbed prey item proliferate and appear to play a direct role in prey degradation. Other larger foraminifera, e.g. Heterostegina depressa and Operculina ammonoides, similarly construct extracellular sheaths which are apparently used to 'farm' bacteria (J. J. Lee pers. comm.). Some of these varied behaviors mirror the intrataxon differences in bacterivory seen in heterotrophic microflagellates (Caron 1987, Sibbald \& Albright 1988), and all highlight the occupation of different niches by benthic foraminifera (reviewed in Lee 1974, Murray 1991).

Previous studies indicate that bacteria are indispensable in the diets of diverse foraminifera (Muller \& Lee 1969). In particular, laboratory feeding experiments revealed that Astrammina rara, Astrorhiza sp., and Glandulina antarctica ingest large numbers of suspended or recently settled bacteria (DeLaca 1985). Why then did these foraminifera fail to harvest bacterial biofilms in our study? It is possible that these species are highly selective feeders (e.g. Lee et al. 1966, Lee \& Muller 1973), and that the mixed enrichment cultures we used failed to supply the favored bacteria (see Brock 1987). Alternatively, these infaunal foraminifera (DeLaca 1986, Bernhard 1989) might be adapted to harvesting discrete patches of bacteria attached to irregular sediment particles rather than continuous biofilms on planar surfaces. Finally, they may simply lack pseudopodial components necessary to dislodge biofilm parcels. The fact that the pseudopodia of larger specimens adhered to the biofilm substratum and exerted sufficient force against it to move their massive bodies suggests that they possess the cytoskeletal elements necessary for the removal of biofilm parcels (reviewed in Travis \& Bowser 1991). Perhaps they lack secreted enzymes (e.g. proteases, glycosidases) which could play a role in biofilm penetration or disaggregation.

It is noteworthy that Elphidium incertum, which like other elphidids (Lopez 1979, Lee et al. 1988b) husbands diatom chloroplasts (Lee \& Lee 1990), did not harvest bacterial biofilms in this study. After reproducing in sediments, this foraminifer is known to live for several months on macrophytes likely to possess biofilms (Matera \& Lee 1972). Although detailed information regarding the diet of $E$. incertum is not yet available, it is possible that the nutrition of this species is fulfilled by consumption of algae and selective husbandry of functional chloroplasts rather than bacterivory. However, the congener E. poeyanum is known to consume large numbers of at least one bacterial species (Lee et al. 1966). Furthermore, laboratory observations indicate that some symbiont-bearing foraminifera (e.g. Amphistegina) can clear algal pastures (Lee et al. 1988a), raising the possibility that these foraminifera express harvesting behavior but discriminate between algal and bacterial mats.

\section{Allogromiid impact on bacterial biofilms}

Considering that Allogromia sp. and A. laticollaris isolates have been obtained from the surfaces of saltmarsh macrophytes (Arnold 1955, Pierce 1965) it is likely that our laboratory findings can be extrapolated to the natural environment. It must be emphasized that, while allogromiids are currently thought to be abundant in only a few environments, very few studies have quantified these small, fragile, nearly transparent organisms (Gooday 1986). Because Allogromia sp. and A. laticollaris are widely distributed in shallow-water locales in the western Atlantic (Freudenthal et al. 1963, Lee \& Pierce 1963, McEnery \& Lee 1976) and the Gulf of Elat (J. J. Lee pers. comm.), and since other allogromiids are common in certain deep-sea environments (Jumars \& Hessler 1976, Gooday 1986, 1988), it seems reasonable that these foraminifera are more abundant than presently appreciated. If so, the results of our study would suggest that allogromiids play a role in biofilm dynamics.

The harvesting activities of allogromiid foraminifera may have diverse influences on biofilm turnover and 
benthic nutrient cycling. For example, biofilm formation is thought to protect attached bacteria from attack by microherbivores, bacteriophages, and chemical agents such as antibiotics (reviewed in Costerton et al. 1987). Regions harvested by allogromiids could provide local sites for bacterial consumption by microherbivores that might not otherwise be able to penetrate these intact biofilm 'defenses.' Similarly, microherbivores could utilize the biofilm fragments generated by allogromiids, which seem especially vulnerable during their transport along pseudopodial surfaces and subsequent accumulation at the cell body. In addition, biofilm harvesting may stimulate the new growth or change the species composition of attached bacterial populations by locally altering the biofilm microenvironment (characterized, e.g., by steep $\mathrm{pH}$ and $\mathrm{O}_{2}$ gradients, which in turn define the types of bacteria present; reviewed in Costerton et al. 1987. Christensen \& Characklis 1990, Blenkinsopp \& Costerton 1991).

\section{Pseudopodial activities effect biofilm harvesting}

Despite the importance of pseudopodial activities in foraminiferal trophic mechanisms (see Lipps 1983 for review), and the importance of bacteria in the nutrition of foraminifera (Muller \& Lee 1969, Lee 1979), the mechanism by which foraminifera acquire bacteria has received little attention. In cinemicrographic and scanning electron microscopic studies of Allogromia motility, McGee-Russell (1974) reported that the 'sweeping' movements of reticulopodia gradually funnelled suspended or loosely-attached bacteria to branch points in the network, where they were phagocytosed by the extension of a cytoplasmic veil (a process classically termed circumvallation; see Kudo 1966). The resulting blister-like phagosomes were then quickly transported to the allogromiid's body, where they fused with lysosomes to effect digestion (Bowser et al. 1985). This pseudopodial sweeping behavior was also seen in our time-lapse recordings, but it failed to detach individual bacteria from the biofilms. Instead, portions of the biofilm were ripped away and transported extracellularly by the distinct invasive and contractile activities of a subset of reticulopodia. It will be interesting to determine how allogromiids distinguish between attached and suspended bacteria in order to trigger the appropriate pseudopodial feeding response (i.e. circumvallation vs harvesting), and future studies of bacterivory in foraminifera should address the relative importance of these feeding mechanisms.

Biofilm harvesting is very similar to the pseudopodial invasive and rending activity, termed skyllocytosis, elicited when Allogromia encounters a boundary of gelled animal or plant material (Bowser 1985). In both processes, the reticulopodia initially invade a gel-like foodstuff, then contract in concert to remove a portion, and finally transport this parcel extracellularly to the cell body. There are subtle differences between biofilm harvesting and skyllocytosis, however. In skyllocytosis, the pseudopodia advance between a hard substratum and the overlying gel to form a wedge-like lamellipodium; the rending activity occurs behind the lamellipodia, along the dorsal reticulopodial surfaces. In the harvesting behavior described here, pseudopodia are deployed over the gel-like material (i.e. the biofilm); lamellipodia are absent and the rending activity occurs along the ventral reticulopodial surfaces. Harvesting and skyllocytosis are probably manifestations of the same basic process influenced by the geometric arrangement of the substratum and foodstuff. In this context, deep-sea allogromiids which quickly inhabit phytodetritus (Gooday 1988, Lochte \& Turley 1988) may use a 3-dimensionai harvesting activity to feed upon the bacteria and cyanobacteria associated with the phytodetritus. In fact, Allogromia sp. has been observed to penetrate an agar substrate while in culture (Pierce 1965), suggesting their ability to invade amorphous plant remains.

\section{Allogromiids display different feeding behaviors}

It is interesting that Allogromia sp. and A. laticollaris exhibit different biofilm harvesting efficiencies. Qualitatively, the 2 species do not differ in their ability to skyllocytose gelatin/agar gels (Bowser 1985). In addition, extensive light- and electron-microscopic studies (reviewed in Travis \& Bowser 1991) have not revealed significant behavioral or morphological differences in their pseudopodia. Nevertheless, we found that $A$. laticollaris displayed a significantly greater range of movement across biofilms and removed significantly smaller parcels than Allogromia sp. Thus, it appears that these congeners utilize distinct foraging strategies: A. laticollaris cursorily exploits large areas whereas Allogromia sp. thoroughly exploits comparatively smaller areas. Our results, which indicate that Allogromia sp. and A. laticollaris differ in their feeding strategies, corroborate the finding that these species have different nutritional requirements, reflected in their mode and rate of reproduction (Lee \& Pierce 1963, Lee et al. 1966. Muller \& Lee 1969; reviewed in Lee 1.974).

In conclusion, the results of this study suggest that allogromiids may have a substantial impact upon attached bacterial populations, whereas other foraminifera may not. Although we examined 2 or more representative species from each of the extant foraminiferal suborders (Allogromiina: Allogromia sp., A. 
laticollaris; Textulariina: Astrammina rara, Astrorhiza sp., Crithionina-like mudball; Miliolina: Cyclogyra antarctica, Pyrgo williamsoni; Rotaliina: Elphidium incertum, Glandulina antarctica), we cannot conclude that bacterial biofilm harvesting is unique to allogromiids: approximately 4000 other tectinous, agglutinated and calcareous species remain to be examined. The importance of foraminiferal biofilm harvesting in the natural environment deserves further study.

Acknowledgements. We thank Drs. J. J. Lee and J. L. Travis for helping us collect and identify marsh foraminifers; Dr S. P. Alexander, Mr R. W. Sanders and Mr N. W. Pollock for their diving expertise during Antarctic operations; and Dr A. B. Leonard for executing the bootstrap analysis. This manuscript benefitted from helpful comments by Drs S. P. Alexander, J. J. Lee, and J. L. Travis. Antarctic field work was made possible by the staffs of the NSF Division of Polar Programs, Antarctic Support Associates, the U.S. Naval Support Force Antarctica, and the crew of Squadron VXE-6. This work was supported by NSF grant DPP 8917375 awarded to S.S.B.

\section{LITERATURE CITED}

Alexander, S. P., DeLdca, T. E. (1987). Feeding adaptations of the foraminiferan Cibicides refulgens living epizoically and parasitically on the antarctic scallop Adamussium colbecki. Biol. Bull. 173: 136-159

Allen, R. D. (1964). Cytoplasmic streaming and locomotion in marine foraminifera. In: Allen, R. D., Kamiya, N. (eds.) Primitive motile systems in cell biology. Academic Press, New York, p. 407-431

Arnold, Z. M. (1955). Life history and cytology of the foraminiferan Allogromia laticollaris. Univ. Cal. Publ. Zool. 61: 167-252

Arnold, Z. M. (1974). Field and laboratory techniques for the study of living foraminifera. In: Hedley, R. H., Adams, C. G. (eds.) Foraminifera, Vol, 1. Academic Press, London, p. 153-206

Bernhard, J. M. (1989). The distribution of benthic foraminifera with respect to oxygen concentration and organic carbon levels in shallow-water Antarctic sediments. Limnol. Oceanogr. 34: 1131-1141

Blenkinsopp, S. A., Costerton, J. W. (1991). Understanding bacterial biofilms. Trends in Biotechnology 9: 138-143

Bowser, S. S. (1985). Invasive activity of Allogromia pseudopodial networks: skyllocytosis of a gelatin/agar gel. J. Protozool. 32: 9-12

Bowser, S. S., DeLaca, T E. (1.985a). Extracellular surface transport in Astrammina rara, a cold-adapted foraminifer. Cell Biol. Int. Rep. 9: 901-910

Bowser, S. S., DeLaca, T E. (1985b). 'Skeletal' elements involved in prey capture by the antarctic foraminiferan Astrammina rara. In: Bailey, G. W. (ed.) Proceedings of the 43rd Annual Meeting of the Electron Microscopy Society of America. San Francisco Press, San Francisco, p. $484-485$

Bowser, S. S., McGee-Russell, S. M., Rieder, C. L. (1985). Digestion of prey in foraminifera is not anomalous: a correlation of light microscopic, cytochemical, and HVEM technics to study phagotrophy in two allogromiids. Tiss. Cell 17: 823-839
Bowser, S. S., DeLaca, T E., Rieder, C. L. (1986). Novel extracellular matrix and microtubule cables associated with pseudopodia of Astrammina rara, a carnivorous Antarctic foraminifer. J. Ultrastruct. Res. 94: 149-160

Bradshaw, J. S. (1961). Laboratory experiments on the ecology of foraminifera. Contrib. Cushman Found. Foram. Res 12: $87-106$

Brock, T D. (1987). The study of microorganisms in situ progress and problems. In: Fletcher, M., Gray, T R. G., Jones, J. G. (eds.) Ecology of microbial communities. Cambridge University Press, New York, p. 1-17

Caron, D. A. (1987). Grazing of attached bacteria by heterotrophic microflagellates. Microb. Ecol 13: 203-218

Characklis, W. G., Marshall, K. C. (1990). Biofilms: a basis for an interdisciplinary approach. In: Characklis, W. G., Marshall, K. C. (eds.) Biofilms. John Wiley and Sons, New York, p. 3-15

Christensen, B. E., Characklis, W. G. (1990). Physical and chemical properties of biofilms. In: Characklis, W. G. Marshall, K. C. (eds.) Biofilms. John Wiley and Sons, New York, p. 93-130

Costerton, J. W., Cheng, K.-J., Geesey, G. G., Ladd, T I. Nickel, J. C., Dasgupta, M., Marrie, T. J. (1987). Bacterial biofilms in nature and disease. Ann. Rev. Microbiol. 41: $435-464$

DeFlaun, M. F. Mayer, L. M. (1983). Relationships between bacteria and grain surfaces in intertidal sediments. Limnol. Oceanogr. 28: 873-881

DeLaca, T. E. (1985). Trophic position of benthic rhizopods in McMurdo Sound. Ant. J. U.S. 20: 147-149

DeLaca, T. E. (1986) The morphology and ecology of Astrammina rara. J. Foram. Res. 16: 216-223

Efron, B., Tibshirani, R. (1991). Statistical data analysis in the computer age. Science 253: 390-395

Ellison, R. L. (1984). Foraminifera and meiofauna on an intertidal mudflat, Cornwall, England: populations; respiration and secondary production; and energy budget. Hydrobiologia 109: 131-148

Frankel, L. (1975). Subsurface feeding in foraminifera. J. Paleontol. 49: 563-565

Freudenthal, H. D., Lee, J J., Pierce, S. (1963). Growth and physiology of foraminifera in the laboratory: Part 2 - A tidal system for laboratory studies on eulittoral foraminifera. Micropaleontology 9:443-448

Gerlach, S. A. (1978). Food-chain relationships in subtidal silty sand marine sediments and the role of meiofauna in stimulating bacterial productivity. Oecologia (Berlin) 33 . $55-69$

Gooday, A. J. (1986). Soft-shelled foraminifera in meiofaunal samples from the bathyal northeast Atlantic. Sarsia 71. 275-287

Gooday, A. J. (1988). A response by benthic foraminifera to the deposition of phytodetritus in the deep sea. Nature, Lond. 332: 70-73

Jones, A. K. (1982). The interaction of algae and bacteria. In: Bull, A. T., Slater, J. H. (eds.) Microbial interactions and communities, Vol. 1. Academic Press, London, p. 189-247

Jumars, P. A., Hessler, R. R. (1976). Hadal community structure: implications from the Aleutian Trench. J. mar. Res. 34: $547-560$

Kudo, R. R. (1966). Protozoology. Charles C. Thomas, Springfield, p. 117-119

Lee, J. J. (1974). Towards understanding the niche of foraminifera. In: Hedley, R. H., Adams, G. (eds.) Foraminifera, Vol. 1. Academic Press, New York, p. 208-257

Lee, J. J. (1979). Nutrition and physiology of the Foraminifera. In: Levandowsky, M., Hutner, S. H. (eds.) Biochemistry 
and physiology of Protozoa, Vol. 3. Academic Press, New York, p. 43-66

Lee, J. J., Lee, R. E. (1990). Chloroplast retention in elphidids (Foraminifera). In: Nardon, P., Gianinazzi-Pearson, V., Greiner, A. M., Margulis, L., Smith, D. C. (eds.) Fourth International Colloquium on Endocytobiology and Symbiosis. Institut National de la Recherche Agronomique, Paris, p. 215-220.

Lee, J. J., Muller, W. A. (1973). Trophic dynamics and niches of salt marsh foraminifera. Am. Zool. 13: 215-223

Lee, J. J., Pierce, S. (1963). Growth and physiology of foraminifera in the laboratory; Part 4 - Monoxenic culture of an allogromiid with notes on its morphology. J. Protozool. 10: $404-411$

Lee, J. J., Erez, J., ter Kuile, B., Lagziel, A., Burgos, S. (1988a). Feeding rates of two species of larger foraminifera, Amphistegina lobifera and Amphisorus hemprichii, from the Gulf of Elat (Red Sea). Symbiosis 5: 61-102

Lee, J. J., Lanners, E., ter Kuile, B. (1988b). The retention of chloroplasts by the foraminifer Elphidium crispum. Symbiosis 5: 45-60

Lee, J. J., McEnery, M., Pierce, S., Freudenthal, H. D., Muller, W. A. (1966). Tracer expenments in teeding littoral foraminifera. J. Protozool. 13:659-670

Lipps, J. H. (1973). Test structure in foraminifera. Ann. Rev. Microbiol. 27: 471-188

Lipps, J. H. (1983). Biotic interactions in benthic foraminifera. In: Tevesz, M. J. S., MicCail, P. L. (eds.) Biotic interactions in recent and fossil benthic communities. Plenum, New York, p. 331-376

Lipps, J. H., Valentine, J W. (1970). The role of foraminifera in the trophic structure of marine communities. Lethaia 3: $279-286$

Lochte, K., Turley, C. M. (1988). Bacteria and cyanobacteria associated with phytodetritus in the deep sea. Nature, Lond. 333:67-69

Lopez, E. (1979). Algal chloroplasts in the protoplasm of three species of benthic foraminifera: taxonomic affinity, viability and persistence, Mar. Biol. 53: 201-211

Marko, M., Leith, A., Parsons, D. (1988). Three-dimensional reconstruction of cells from serial sections and whole-cell mounts using multilevel contouring of stereo micrographs. J. Electron Microsc. Tech. 9: 395-411

This article was presented by E. and B. Sherr, Corvallis, Oregon, USA
Matera, N. J., Lee, J. J. (1972). Environmental factors affecting the standing crop of foraminifera in sublittoral and psammolittoral communities of a salt marsh. Mar. Biol. 14: 89-103

McEnery, M. E., Lee, J. J. (1976). Allogromia laticollaris: a foraminiferan with an unusual apogamic metagenic life cycle. J. Protozool. 23: 94-108

McFeters, G. A., Brazin, M. J., Bryers, J. D., Caldwell, D. E, Characklis, W. G., Lund, D. B., Mirelman, D., Mitchell, R., Schubert, R. H. W., Tanaka, T., White, D. C. (1984). Biofilm development and its consequences. In: Marshall, K. C. (ed.) Microbial adhesion and aggregation. Dahlem Konferenzen. Springer-Verlag, Berlin, p. 109-124

McGee-Russell, S. M. (1974). Dynamic activities and labile microtubules in cytoplasmic transport in the marine foraminiferan Allogromia. Symp. Soc. exp. Biol. 28: $157-189$

Muller, W. A., Lee, J. J. (1969). Apparent indispensability of bacteria in foraminiferan nutrition. J. Protozool. 16: $471-478$

Murray, J. W. (1991). Ecology and distribution of benthic foraminifera. In: Lee, J. J., Anderson, O. R. (eds.) Biology of Foraminitera. Academic Press, London, p. 221-253

Paerl, H. W. (1984). Alteration of microbial metabolic activities in association with detritus. Bull. mar. Sci. 35: 393-408

Pierce, S. (1965). A comparative study of two members of the Family Allogromiidae (Protozoa, Foraminiferida). Ph.D. dissertation, New York University

Sibbald, M. J., Albright, L. J. (1988). Aggregated and free bacteria as food sources for heterotrophic microflagellates. Appl. environ. Microbiol. 54: 613-616

Travis, J. L., Allen, R. D. (1981). Studies on the motility of the foraminifera $I$. Ultrastructure of the reticulopodial network of Allogromia laticollaris (Arnold). J. Cell Biol. 90: 211-221

Travis, J. L., Bowser, S. S. (1991). The motility of foraminifera. In: Lee, J. J., Anderson, O. R. (eds.) Biology of the Foraminifera. Academic Press, London, p. 91-155

Travis, J. L., Bowser, S. S., Calvin, J G., Lee, J. J (1988). Pseudopodial tension in Amphisorus hemprichii, a giant Red Sea foraminifer. Protoplasma (Suppl. 1): 64-71

Zobell, C. E. (1943). The effect of solid surfaces upon bacterial activity. J. Bacteriol. 46: 39-56

Manuscript first received: October 7, 1991

Revised version accepted: March 19, 1992 